\title{
POLÍTICAS PÚBLICAS E SEU CARÁTER INTERDISCIPLINAR
}

MARCHETTI, Vitor (Org.). Políticas públicas em debate. São Bernardo do Campo, SP: MP Editora, 2013, 320 p.

Marina Morais de Andrade*

O livro "Políticas Públicas em debate" resultou de um curso de extensão realizado pelo Bacharelado de Políticas Públicas da Universidade Federal do $A B C$ (UFABC) para os principais sindicatos da região do $\mathrm{ABC}$, com o intuito de aproximar os laços e de capacitar os líderes sindicais aprofundando em discussões de políticas públicas nas mais diversas áreas. A UFABC e os sindicatos têm sido parceiros nas proposições de desenvolver o potencial da região. Na apresentação do livro, escrita pelas direções dos sindicatos, é afirmada a importância de se construir este trabalho conjunto, tendo em vista que a Universidade também resultou das lutas sindicais.

Para os autores a obra traduz dois momentos caros à região: a consolidação da UFABC e o aprofundamento das reflexões no campo de políticas públicas, um novo campo acadêmico. A UFABC se insere em um contexto de reforma do ensino superior, com a introdução dos bacharelados interdisciplinares e com as políticas de cotas sociais e raciais, enquanto o campo de políticas públicas surge em âmbito acadêmico como uma inovação que busca o aperfeiçoamento da ação governamental e consolidação da democracia.

* Mestranda do Programa de Pós-Graduação de Ciências Humanas e Sociais na Linha de Pesquisa Estado e Políticas Públicas na Universidade Federal do ABC (UFABC) e bolsista Capes. E-mail: marina.moraisdeandrade@gmail.com. 
A primeira parte do livro, composta pelos três primeiros capítulos, trata as bases teóricas do campo de políticas públicas. No primeiro Capítulo Vanessa de Oliveira aborda o "ciclo de políticas públicas" sob a nomenclatura de "fases do processo de políticas públicas". Este capítulo se propõe a fazer uma revisão bibliográfica de autores que tratam as fases do processo, focandose nas que ainda são pouco estudadas: implementação e avaliação.

No segundo Capítulo, o autor Vitor Marchetti apresenta três correntes que procuram avaliar o desempenho do desenho institucional do governo brasileiro. As três correntes buscam responder se é preciso reformar ou não o desenho institucional para garantir governabilidade e qualidade à democracia brasileira. $\mathrm{O}$ autor conclui que, muito embora já se discuta o tema com mais desenvoltura e criticidade, existem novos possíveis caminhos a serem percorridos.

No Capítulo 3, Sidney Jard e Simone Diniz, ao tratarem do tema “Reforma previdenciária, sindicalismo e processo decisório na Argentina e no Brasil" procuram apresentar como os arranjos institucionais podem influenciar o processo decisório de uma política pública. De uma forma clara e com exemplos empíricos, os autores conseguem demonstrar ao leitor as influências do desenho institucional na negociação do processo de formulação de uma política pública.

Com o início do quarto Capítulo o leitor adentra na segunda parte do livro em que são debatidos temas tradicionais de políticas públicas setoriais. Desta maneira, no Capítulo 4, Artur Zimerman trata o tema da "Segurança Pública no Brasil". O autor inicia a discussão apresentando os crescentes e alarmantes índices de homicídios no Brasil. Segundo os dados demonstrados existe um grupo que compõe majoritariamente esta estatística: homens, negros, jovens que moram em regiões metropolitanas. Segundo ele, este grupo seria vítima principal dos homicídios por conta da pobreza e desigualdade existente no Brasil. Contudo, acreditase também que a questão do racismo, não abordada pelo autor, seja um fator fundamental para a vitimização deste grupo. Como formas de combate à violência, Zimerman se foca na discussão da 
Segurança Pública. Apesar das críticas existentes às Unidades da Polícia Pacificadora (UPPs), o autor as considera como políticas de sucesso. Ao finalizar o texto enfatiza algumas sugestões para superar o problema da violência.

Já no Capítulo 5 do livro são tratadas as políticas educacionais brasileiras em perspectiva histórica pela professora Maria Gabriela Marinho. Inicialmente a autora se detém a matriz intelectual e institucional dos sistemas educacionais modernos: as experiências europeias. A partir disso, se debruça na análise da experiência brasileira no campo das políticas educacionais e sua interlocução com a matriz europeia. Ao longo do texto Marinho demonstra que no Brasil foi seguido o modelo educacional napoleônico implementado na França, caracterizado por suas políticas centralizadas e universais.

No Capítulo 6 do livro, Gerardo Silva trata da "Política Cultural no Brasil". Em princípio, o texto se foca na análise crítica da perspectiva neoliberal das políticas culturais brasileiras, adotada a partir de 1990, que tem na Lei Rouanet a sua maior expressão. Para o autor a entrada Gilberto Gil no Ministério da Cultura (2003) faz com que se inicie uma nova fase permeada por uma visão antropológica da cultura, com vistas a fomentar a produção cultural autônoma, muito embora permaneçam ainda hoje os incentivos fiscais resultados da década de liberalização que favorecem as produções mercadológicas. O texto desperta muito interesse pelas políticas culturais ao fazer uma análise sintética e esclarecedora capaz de fazer com que leigos consigam se aprofundar em discussões importantes relacionadas ao tema.

Outra política específica abordada nesta parte do livro diz respeito ao transporte urbano no Brasil. A autora do Capítulo 7, Silvana Zioni, busca relacionar o histórico das políticas de transporte urbano com as políticas de desenvolvimento adotadas desde a Primeira República. A autora demonstra que na maior parte do período analisado as políticas de transporte e, particularmente, o urbano estiveram submetidas às outras políticas, como de energia, saneamento, habitação, etc, não existindo até muito recentemente políticas voltadas especificamente para esta área. 
Em continuidade com o debate da questão urbana trazido no texto anterior, Ricardo Moretti trabalha no Capítulo 8 com o tema "Urbanismo e Saneamento no início do século XX e seus reflexos no quadro atual". O autor aborda as influências das medidas sanitaristas na urbanização das cidades brasileiras, concluindo que as políticas de urbanização viriam como um subproduto das sanitaristas. Isto culminaria mais tarde na construção de cidades dependentes de recursos externos, poluídas e poluidoras, com riscos de enchentes, falta de água e de energia.

Permanecendo na questão urbana, só que com outro foco, a autora Maria de Lourdes Fonseca em "Uma aproximação do planejamento urbano no Brasil" aponta outros principais problemas enfrentados pelas cidades brasileiras. Nesse escopo, apresenta como principal raiz destes problemas o padrão de crescimento periférico que tem sua fonte nos movimentos empreendidos pelo capital fundiário e especulativo. A autora também entende que os planos diretores não passam de discursos ideologizados construídos pelas elites locais. Esta análise crítica possibilita ao leitor compreender a profundidade dos problemas a serem enfrentados para superar os entraves políticos, econômicos e sociais existentes para o desenvolvimento das cidades brasileiras.

A partir do Capítulo 10 inicia-se a terceira parte do livro, composta por temas emergentes de políticas públicas que merecem atenção. Neste Capítulo, por exemplo, o professor Giorgio Schutte trabalha com a problemática da "Política Externa brasileira como uma política pública". O autor aborda a política externa integrada ao projeto de desenvolvimento nacional e enfatiza a necessidade de democratizá-la, de maneira a possibilitar maior participação social na sua formulação. Em continuidade com a discussão das políticas de caráter internacional, no Capítulo 11, José Blanes e Fagner Carvalho abordam o fato de muitos governos federados estarem se engajando em políticas internacionais. Afirmam existir a intensificação deste movimento de atuação internacional dos municípios brasileiros, desde 1988, como uma nova forma de buscar alternativas para suprir as demandas locais. 
Já no Capítulo 12 são tratados os "Aspectos das trajetórias das políticas públicas de ciência, tecnologia e inovação no Brasil" desde a década de 1930. Os autores Anapatrícia Vilha, Marcos Fuck e Maria Bonacelli se propõem a demonstrar os atores e instituições influentes em cada fase destas políticas no Brasil. $\mathrm{Na}$ abordagem dão destaque à dependência tecnológica brasileira, a qual tem suas raízes no processo de industrialização tardia e no fato de este setor receber predominantemente investimentos públicos e pouca atenção por parte dos empresários brasileiros. Em prosseguimento com as discussões deste tema, Neusa Serra apresenta no Capítulo 13 o cenário brasileiro nesta área. No caso do estado de São Paulo, embora sua produção de conhecimento acadêmico se destaque por seus números, as empresas localizadas em seu território ainda têm apresentado baixos índices de inovação. A autora acredita existir uma distância entre a academia e a indústria que precisa ser superada.

Por fim, na tentativa de trazer à discussão outro tema emergente, Claudio Penteado aborda no último Capítulo reflexões sobre a existência de uma relação entre mídia e políticas públicas, tendo em vista que a mídia é o principal meio que concede visibilidade às ações políticas atualmente. Assim, a mídia pode se constituir um instrumento que dê transparência às políticas públicas, pode ser um meio de controle, denúncia, participação e pressão. Os meios midiáticos também podem contribuir para a democratização do país, ao abrir espaço para discursos alternativos, ou então prejudicar o processo de democratização, como no caso dos meios de massa que possuem uma lógica do espetáculo. Sendo assim, o estudo da comunicação política, para o autor, merece e é importante que seja objeto de novas pesquisas.

É desta maneira que o livro oferece ao leitor abordagens teóricas e de políticas específicas, de temas tradicionais e emergentes, de maneira a introduzir diferentes discussões com conteúdo e criticidade, apresentando um panorama geral de como caminham algumas questões de políticas públicas muito caras ao desenvolvimento brasileiro e como todas elas se interconectam revelando o seu caráter interdisciplinar. 
|308|

Resenha

\section{Bibliografia}

MARCHETTI, Vitor (Org.). Políticas públicas em debate. São Bernardo do Campo, SP: MP Editora, 2013, 320 p. 